\title{
SYNCHRONOUS FLYBACK CONVERTER WITH SYNCHRONOUS BUCK POST REGULATOR
}

\author{
Navnit Kumar ${ }^{1}$, S.Pradeepa ${ }^{2,}$ Mohan HR $^{3}$ \\ ${ }^{1}$ PG Scholar, Power Electronics (Department of EEE), BMS College of Engineering, Bangalore, India \\ ${ }^{2}$ Associate Professor, Power Electronics (Department of EEE), BMS College of Engineering, Bangalore, India \\ ${ }^{3}$ Deputy Manager, Central D\&E (power supply), Bharat Electronics Limited, Bangalore, India
}

\begin{abstract}
In general, conventional converter is used for converting the power level from one stage to another. But conventional type of converter has slightly more power losses \& voltage drop, so efficiency is very sensitive for the low voltage specification and also cooling of dissipative elements floating at higher voltages is a difficult task. So high efficient scheme of synchronous flyback converter with synchronous buck post regulator was approached and low voltage drop, less power losses \& very high efficiency was achieved. Where the secondary side of flyback converter including Synchronous buck post regulator floats on the very high voltage line (i.e. $10 \mathrm{kV}$ ) for the Filament power supply heats the cathode to required temperature to emit electrons in TWT. Filament Power supply based on the Fly back Converter topology which is operated at $100 \mathrm{KHz}$ in CCM mode The Pulse width modulation technique is used to maintain the voltage at desired value using IC. The Post regulator using Synchronous buck topology is implemented for regulating the output voltage of synchronous flyback converter $(9.5 \mathrm{~V} D C)$ to Regulated $6.3 \mathrm{~V} @ 3.3 \mathrm{~A} D \mathrm{D}$.
\end{abstract}

Keywords: CCM (Continuous current mode), Pulse width modulation (PWM), synchronous Buck Regulator, Synchronous Flyback converter, TWT (Travelling Wave Tube), SR (Synchronous Rectifier).

\section{INTRODUCTION}

The conduction loss of diode rectifier contributes significantly to the overall power loss in a power supply, especially in low output voltage applications. The rectifier conduction loss is proportional to the product of its forward-voltage drop, $\mathrm{V}_{\mathrm{F}}$, and the forward conduction current, $\mathrm{I}_{\mathrm{F}}[1]$.

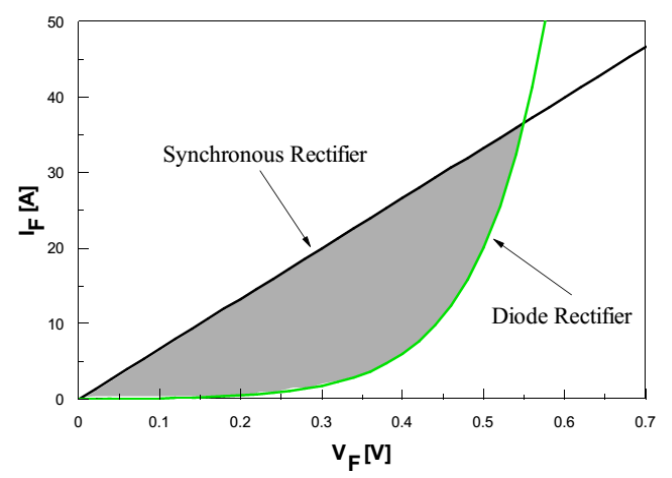

Fig -1: Forward-voltage comparison between synchronous rectifier and diode rectifier. $\square$ area has conduction loss saving by using synchronous rectifiers [1].

On the other hand, operating in the MOSFET III quadrant, a synchronous rectifier presents a resistive i-v characteristics, as shown in Fig.1.
Under certain current level, the forward-voltage drop of a synchronous rectifier can be lower than that of a diode rectifier, and consequently reduces the rectifier conduction loss. Due to the fact that synchronous rectifiers are active devices, the design and utilization of synchronous rectification need to be properly addressed.

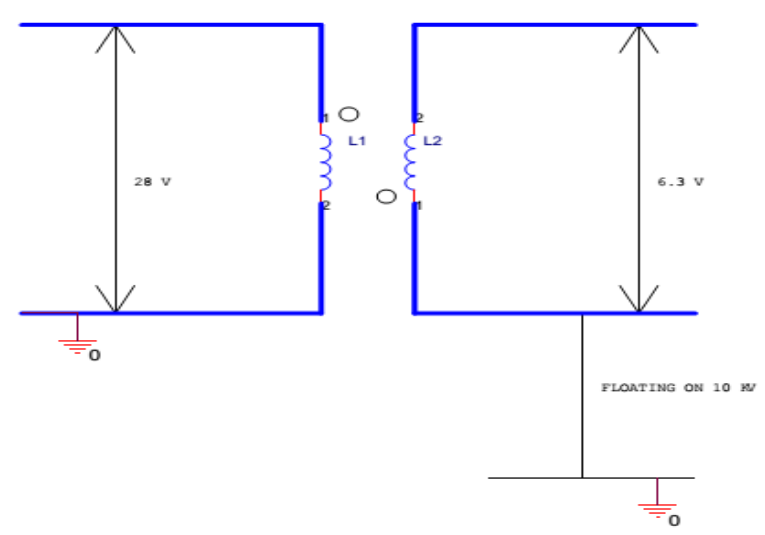

Fig -1.1: Flyback Transformer

This paper analyses the application of synchronous rectification in two most popular topologies, flyback \& Buck converters. The limits of efficiency improvements that can be 
obtained using synchronous rectification are determined. Conversion efficiencies of different implementations are compared, and verified with experimental evaluations. Here secondary side of flyback converter will be floating on very high voltage line (i.e. $10 \mathrm{kV}$ or more). So it is very difficult to take feedback signal for control circuit from secondary side of synchronous flyback converter to primary side, because voltage level of primary side is $28 \mathrm{~V}$ DC whereas voltage level of secondary side of flyback converter is $10 \mathrm{kV}$ with respect to ground, as shown in fig. 1.1. Hence there is a need for highly efficient post regulator as a next stage to the flyback converter to obtain regulated $6.3 \mathrm{~V}$ DC from $28 \pm 0.5 \mathrm{~V}$ DC input. Highly efficient post regulator was implemented using synchronous buck topology.

\section{SYNCHRONOUS FLYBACK CONVERTER}

A flyback converter with the SR (Synchronous Rectifier) is shown in Fig 2. For proper operation of the converter, conduction periods of primary switch SW and secondary-side switch SR must not overlap.

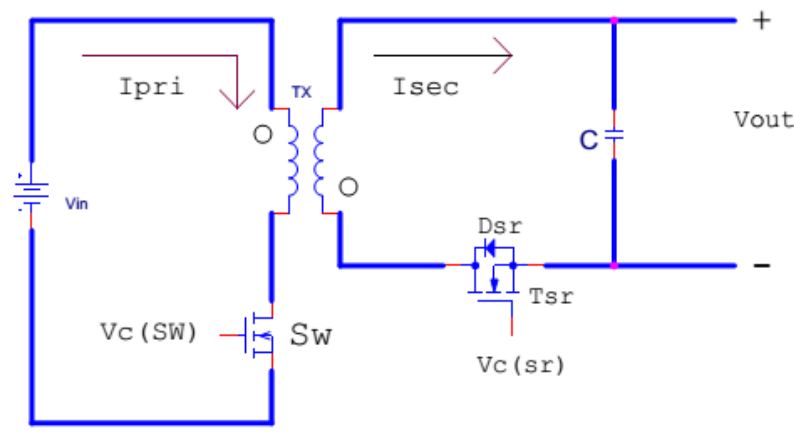

Fig -2: Synchronous flyback converter

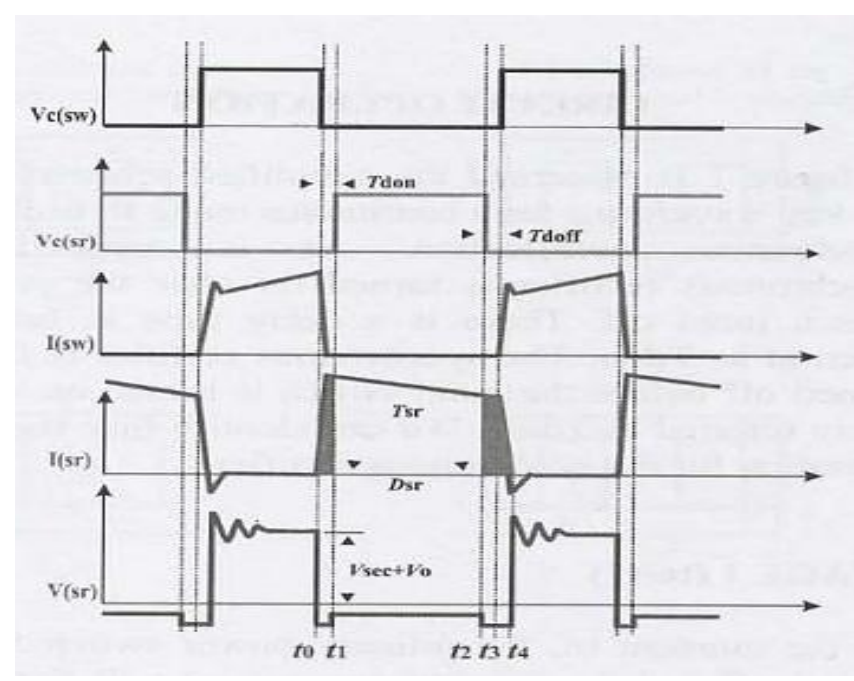

Fig -2.1: Expected waveform of synchronous flyback converter [2].
To avoid the simultaneous conduction of the SW and the SR, a delay between the turn off instant of switch SW and the turnon instant of the SR as well as between the turn-on instant of the SW and turn-off instant of the SR must be introduced in the gate-drive waveforms of the switches as in Fig 2.1[2]. With properly designed gate drives, the operation of the circuit shown in Fig. 2 is identical to that with a conventional diode rectifier. Namely, during the time switch SW is turned on, energy is stored in the transformer magnetizing inductance and transferred to the output after SW is turned off.

\subsection{Design and Simulation Result of SR Flyback}

\section{Converter:}

Specifications:

Input Voltage $\mathrm{V}_{\text {in }}(\mathrm{dc})=(28 \pm 0.5) \mathrm{V}$,

Switching Frequency $=100 \mathrm{KHz}$,

Outputs Specifications: $(9.5 \mathrm{~V}, 2 \mathrm{~A}), \mathrm{P}_{0 \min }=6$ watts

Step 1: Establish primary \& secondary turn Ratio:

$$
\begin{aligned}
\frac{\mathrm{N}_{\mathrm{p}}}{\mathrm{N}_{\mathrm{s}}} & =\frac{\left(\mathrm{V}_{\mathrm{dcmin}}-1\right) \mathrm{D}_{\max }}{\left(1-\mathrm{D}_{\max }\right)\left(\mathrm{V}_{0}+1\right)} \\
& =2.0649
\end{aligned}
$$

Where $\mathrm{D}_{\max }=0.45$ (assumed)

Step 2: Voltage stress of main switch (SW):

$$
\begin{aligned}
V_{\text {ms } \max } & =V_{d c \max }+\frac{\mathrm{N}_{\mathrm{p}}}{\mathrm{N}_{\mathrm{g}}} *\left(\mathrm{~V}_{0}+1\right) \\
& =50.182 \mathrm{~V}
\end{aligned}
$$

Where $\mathrm{V}_{\mathrm{dc} \max }=$ Maximum dc input voltage.

$\mathrm{V}_{\mathrm{ms} \max }=$ Maximum stress on the device $\left(2 * \mathrm{~V}_{\mathrm{dc} \max }\right)$.

$\mathrm{N}_{\mathrm{P}}=$ Primary no of turns.

$\mathrm{N}_{\mathrm{s}}=$ Secondary no of turns (main output).

$\mathrm{V}_{0}=$ Output Voltage.

Step 3: Calculation of primary magnetizing Inductance (Lp):

$$
\begin{aligned}
\mathrm{L}_{\mathrm{p}} & =\frac{\left(\mathrm{V}_{\mathrm{dcmin}}-1\right) * \mathrm{~V}_{\mathrm{dcmin}} *\left(\mathrm{~T}_{\text {onmax }}\right)^{2}}{2.5 * \mathrm{P}_{0 \min } * \mathrm{~T}_{\mathrm{S}}} \\
& =98.38 \mu \mathrm{H}
\end{aligned}
$$

Where, given: $\mathrm{f}=100 \mathrm{kHz}, \mathrm{D}=0.45, \mathrm{P}_{0 \text { min }}=6$ watts; $\mathrm{S} 0, \mathrm{~T}=1 / \mathrm{f}$ $=10 \mu \mathrm{s} ; \mathrm{T}_{\text {on } \max }=\mathrm{D}^{*} \mathrm{~T}=4.5 \mu \mathrm{s}$.

Step 4: Calculation of primary peak current $\left(\mathrm{I}_{\mathrm{cpr}}\right)$ :

$$
I_{c p r}=\frac{1.25 * P_{0 \max }}{V_{d c \min } * D_{\max }}
$$




$$
=1.919 \mathrm{~A}
$$

Ramp amplitude $\mathrm{dI}_{\mathrm{p}}$

$$
\begin{aligned}
\mathrm{dI}_{\mathrm{p}} & =\frac{2.5 * \mathrm{P}_{\mathrm{o} \min }}{\mathrm{V}_{\mathrm{demin}} * \mathrm{D}_{\max }} \quad\left(\text { Let } \mathrm{P}_{0 \text { min }}=6 \mathrm{~W}\right) \\
& =1.21 \mathrm{~A}
\end{aligned}
$$

Therefore peak current in the mosfet $=\mathrm{Icpr}+(\mathrm{dIp} / 2)$

$$
=2.52 \mathrm{~A}
$$

Step 5: Calculation of secondary peak current $\left(\mathrm{I}_{\mathrm{csr}}\right)$ :

$$
\begin{aligned}
I_{c s r} & =\frac{P_{0 \max }}{V_{0}\left(1-D_{\max }\right)} \\
& =3.6 \mathrm{~A}
\end{aligned}
$$

Average of $I_{c s r}$ gives secondary load current

$$
\text { i.e., } \mathrm{I}_{\mathrm{csr}}\left(1-\mathrm{D}_{\max }\right)=1.98 \mathrm{~A}
$$

Step 6: Output filter capacitor $\mathrm{C}_{0}$ :

$$
\begin{aligned}
\mathrm{C}_{0} & =\frac{\mathrm{D}_{\max } * \mathrm{P}_{0}}{\mathrm{~F}_{\mathrm{sw}} * \mathrm{~V}_{0} * \Delta \mathrm{V}_{0}} \quad\left(\text { Take } \Delta \mathrm{V}_{0}=39 \mathrm{mV}\right) \\
& =231 \mu \mathrm{F}
\end{aligned}
$$

Choose a cap of $\mathrm{C}_{0}=300 \mu \mathrm{F}$.

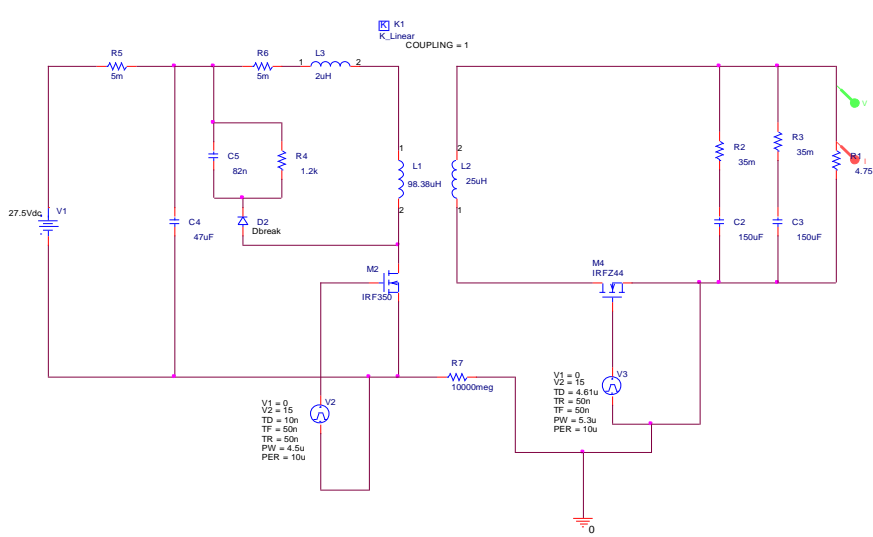

Fig -2.2: Simulation circuit of SR flyback converter

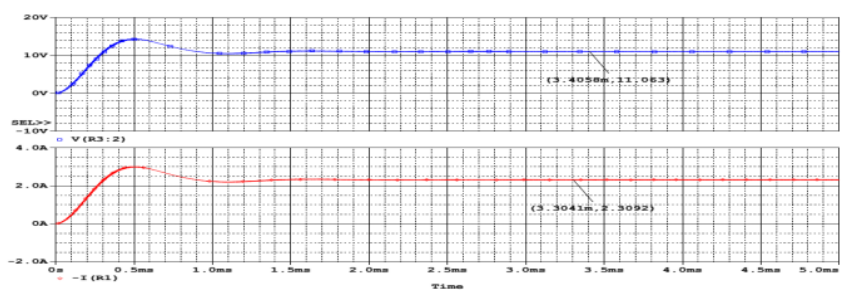

Fig -2.3: Output voltage and current of synchronous flyback Converter

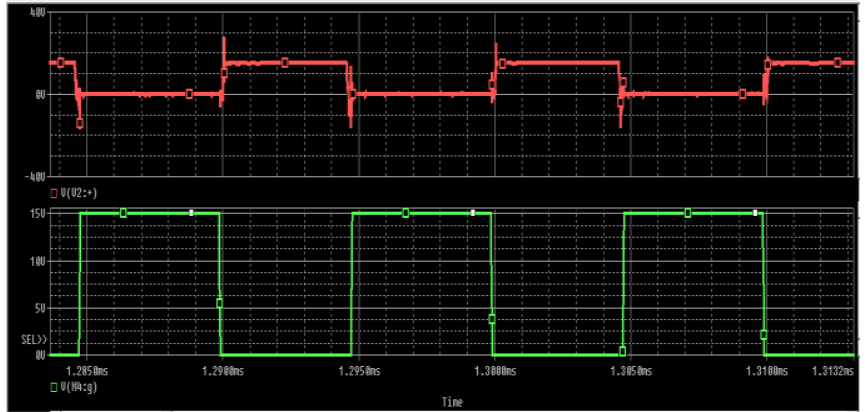

Fig -2.4: Gate pulse of primary and secondary mosfet
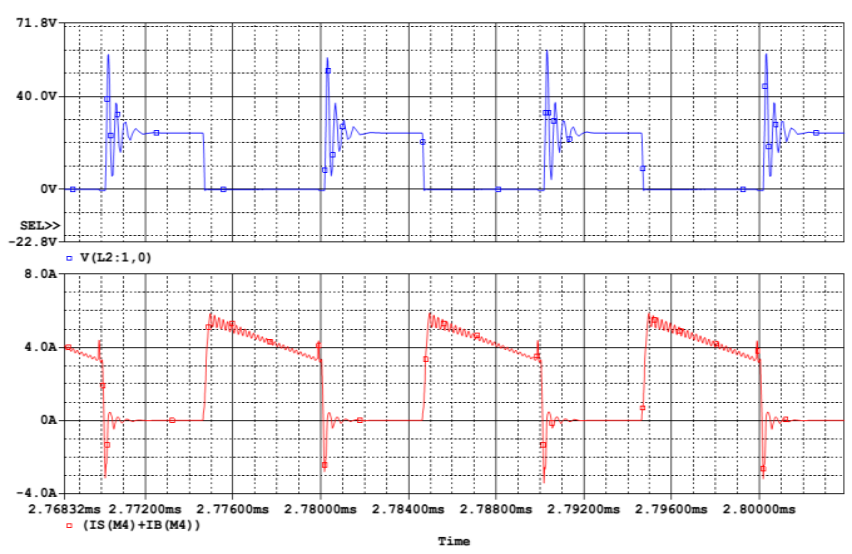

Fig -2.5: Waveform of $\mathrm{V}(\mathrm{sr})$ and $\mathrm{I}(\mathrm{sr})$ of mosfet (M4).

\subsection{Transformer Design}

Area product of flyback converter:

$A_{p}=\left[\frac{\mathrm{L}_{\mathrm{p}} * \mathrm{I}_{\text {peak }} * \mathrm{I}_{\mathrm{rmg}} * 10^{4}}{420 * \mathrm{k} * \mathrm{~B}_{\max }}\right]^{1.31}$

Where $A_{p}=$ area product in $\mathrm{cm}^{4}, \mathrm{~K}=$ winding factor, 0.2 for continuous mode flyback, $\mathrm{B}_{\max }=\mathrm{B}_{\text {sat }}$ in tesla @ $100^{\circ} \mathrm{C}$

$$
\begin{aligned}
I_{\text {rmas }} & =\sqrt{D_{\text {max }} *\left[\left(I_{\text {peak }}\right)^{2}-\Delta I_{L} * I_{\text {peak }}+\frac{\left(\Delta H_{L}\right)^{2}}{a}\right]} \\
& =1.3058 \mathrm{~A}, \text { where } \Delta \mathrm{p}=\Delta \mathrm{I}_{\mathrm{L}}=1.21 \mathrm{~A}
\end{aligned}
$$

Therefore area product required

$$
\begin{aligned}
A_{p} & =\left[\frac{L_{p} * I_{\text {peak }} * I_{r m s} * 10^{4}}{420 * k * B_{\max }}\right]^{1.31} \\
& =0.29 \mathrm{~cm}^{4}=2900 \mathrm{~mm}^{4}
\end{aligned}
$$

Now select ETD 39 Core and core material is N87.

$$
\mathrm{A}_{\mathrm{e}}=125 \mathrm{~mm}^{2} \text { for } \mathrm{N} 87
$$

Calculation of primary turns

$$
\mathrm{N}_{\mathrm{p}}=\left(\mathrm{L}_{\mathrm{p}} * \mathrm{I}_{\mathrm{p}}\right) /\left(\mathrm{B}_{\mathrm{m}} * \mathrm{~A}_{\mathrm{e}}\right)
$$


$\mathrm{N}_{\mathrm{p}}=8$ turns, so taking $\mathrm{N}_{\mathrm{p}}=10$ turns

Calculation of secondary turns $\mathrm{N}_{\mathrm{s}}$

$$
\begin{aligned}
& \frac{N_{D}}{N_{s}}=2.065 \\
& N_{s}=5 \text { Turns. }
\end{aligned}
$$

Primary and secondary wire selection:

Skin depth calculation

Skin depth $=\frac{66}{\sqrt{f_{5}}} \mathrm{~mm}$

$\mathrm{f}_{\mathrm{s}}=$ switching frequency $=100 \mathrm{kHz}$

Skin depth $=\frac{66}{\sqrt{100 \mathrm{~K}}}$

$=0.2087 \mathrm{~mm}$

So, wire diameter should be $<2 * 0.2087 \mathrm{~mm}$.

Now wire selection is done accordingly and $10 \mathrm{kV}$ isolation requirements between primary/secondary windings and secondary winding/core are met using polyimide sheet in flyback Transformer, as shown in Fig. 2.6.

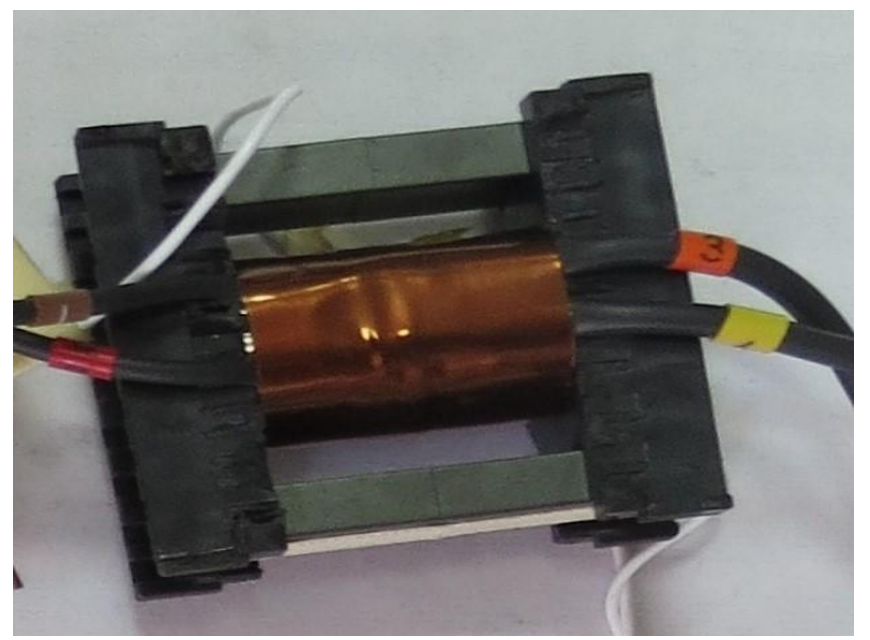

Fig -2.6: ETD core Transformer.

\subsection{PWM Controller for Synchronous Flyback}

\section{Converter}

UC28025: For primary side control of SR flyback converter PWM IC UC28025 is used, which is a fixed-frequency PWM controller optimized for high-frequency SMPS applications. Targeted for cost effective solutions with minimal external components, UC28025 include an oscillator, a temperature compensated reference, a wide band width error amplifier, a high-speed current-sense comparator and high-current activehigh totem-pole outputs to directly drive external MOSFETs.

FAN6204: FAN6204 is selected for secondary side of synchronous rectification (SR) controller. FAN6204, which is suitable for Continuous Conduction Mode (CCM) and also suitable for Discontinuous Conduction Mode (DCM) / QuasiResonant (QR) flyback converters and dual-switch forward free-wheeling rectification (Figure 2.7) [7]

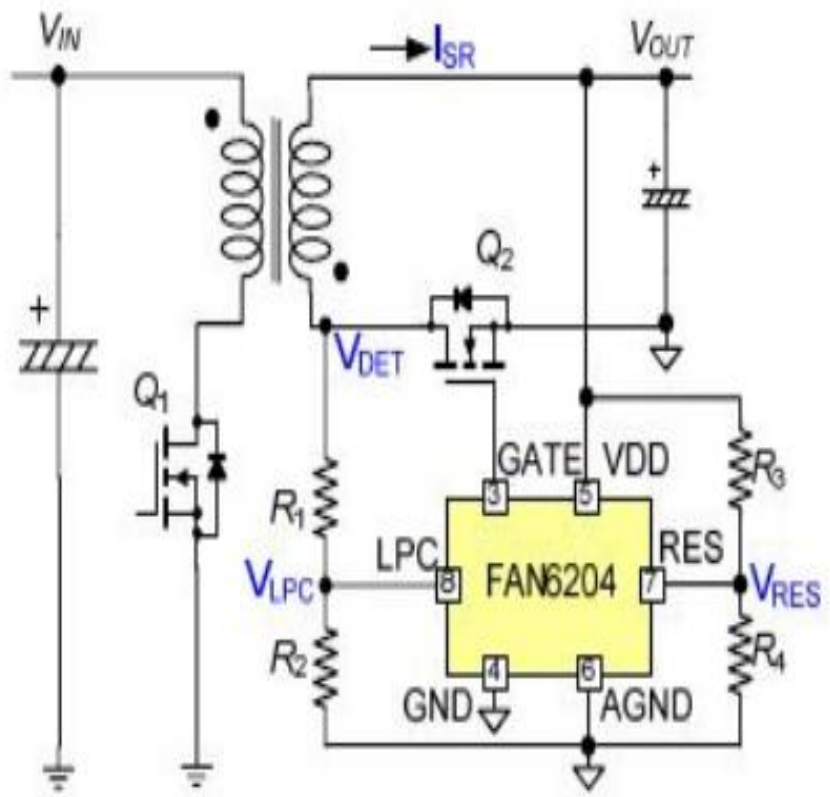

Fig -2.7: Typical Application Circuit for Flyback Converter[7].

FAN6204 utilizes a proprietary innovative linear-predict timing control to determine the turn-on and turn-off timing of SR MOSFET [7]. This control technique detects the voltage of the transformer winding and output voltage instead of MOSFET current, so noise immunity can be accomplished. Furthermore, this technique doesn't need a communication signal from the primary side, so this feature reduces external components and simplifies PCB layout. This is also easier for implementation, in high voltage applications, where transferring timing signals across the isolation barrier is difficult.

\section{SYNCHRONOUS BUCK REGULATOR}

The simplest way to get a regulated output by using linear regulator, but with linear regulators there is a dissipation of the order of 1.5 to $2 \mathrm{~W}$ for any 15 to $20 \mathrm{~W}$ converters which makes heat removal from the elements floating at higher voltages cumbersome. Hence there is a need for switching post regulator. Buck converter (step down) is the simplest solution but Synchronous Buck regulator, on the other hand, can be remarkably efficient (95\% or higher). 


\subsection{Asynchronous Buck Topology}

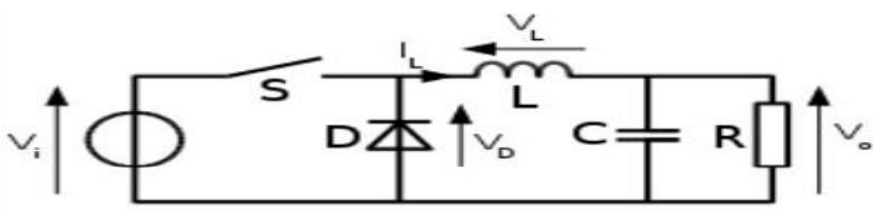

Fig -3.1: Asynchronous buck converter

A typical asynchronous buck regulator circuit is as shown in the figure 3.1 above. ' $S$ ' denotes a MOSFET being used in the top side with a diode ' $\mathrm{D}$ ' in the bottom side. These are the two main switches that control power to the load. When the MOSFET is turned ON, $V_{\text {IN }}$ charges the inductor ' $L$ ', capacitor ' $\mathrm{C}$ ' and supplies the load current. Upon reaching its set output voltage the control circuitry turns OFF the MOSFET (hence called a switching MOSFET). Switching OFF the top side MOSFET disrupts the current flowing through the inductor. With no path for the current, the inductor will resist this change in the form of a catastrophic voltage spike. To avoid this spike when the top side MOSFET is turned OFF, a path is provided for the inductor current to continue flowing in the same direction as it did before. This is created by the bottom side diode ' $D$ '. When the top side MOSFET turns OFF, the inductor voltage reverses its polarity forward biasing the diode ' $\mathrm{D}$ ' on, allowing the current to continue flowing through it in the same direction. When current flows in the diode, it is also known as being in freewheel mode. When the output voltage drops below the set point, the control will turn ON the top side MOSFET and this cycle repeats to regulate the output voltage to its set value.

\subsection{Synchronous Buck Topology}

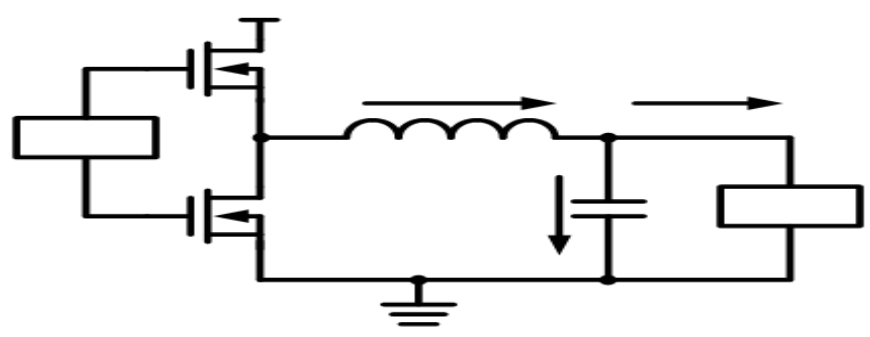

(a)

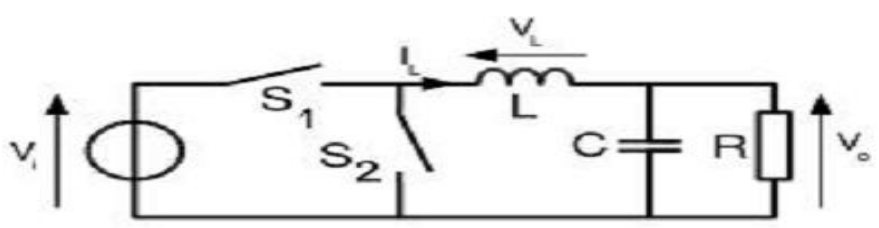

(b)

Fig -3.2: (a) and (b) Simplified schematic of a synchronous converter, in which D is replaced by a second switch,S2.
The synchronous topology is depicted in the fig.3.2 above. The bottom side diode ' $\mathrm{D}$ ' has been replaced with another MOSFET, 'S2.' Since there are two MOSFETs ' $\mathrm{S} 1$ ' is called the high-side MOSFET and 'S2' the low-side MOSFET. The low-side MOSFET is also referred to as the synchronous MOSFET while the high-side MOSFET is called the switching/control MOSFET. In steady state, the low-side MOSFET is driven such that it is complimentary with respect to the high-side MOSFET. This means whenever one of these switchesis ON, the other is OFF. In steady state conditions, this cycle of turning the high-side and low-side MOSFETs ON and OFF complimentary to each other regulates $\mathrm{V}_{\text {OUT }}$ to its set value.Observe that the low-side MOSFET will not turn ON automatically. This action needs additional MOSFET drive circuitry within the control IC to turn ON and OFF as needed.

Compare this to asynchronous topology where the polarity reversal across the inductor automatically forward biases the diode,completing the circuit. In both the asynchronous and synchronous topologies, the effective switch is the high-side MOSFET. It is the switch which dictates when to build up energy in the inductor and when to force the inductor current to start freewheeling.

In the synchronous topology the low-side MOSFET's lower resistance from drain to source $\left(\mathrm{RDS}_{\mathrm{ON}}\right)$ helps reduce losses significantly and therefore optimizes the overall conversion efficiency.

\subsection{Design and Simulation Result of Synchronous \\ Buck Regulator}

Specifications: Input Voltage $\mathrm{V}_{\text {in }}(\mathrm{dc})=$ Output of synchronous flyback converter $=9.5 \mathrm{~V}$, Switching Frequency $=100 \mathrm{KHz}$, Outputs Specifications: $(6.3 \mathrm{~V}, 3.3 \mathrm{~A})$.

Step1: Calculation of Inductance (L)

$\mathrm{T}_{\mathrm{s}}=1 / \mathrm{f}_{\mathrm{s}}=10 \mu \mathrm{s}, \mathrm{D}=\mathrm{V}_{0} / \mathrm{V}_{\text {in }}=66 \%, \mathrm{P}_{\text {out }}=20.79$ Inductor will be chosen so that the current remains continuous if the DC output current stays above a specified minimum value. (Typically this is chosen to be around $10 \%$ of the rated load current, or $0.1 * \mathrm{I}_{0}$, where " $\mathrm{I}_{0}$ " is defined as the nominal output current.)

Therefore, $\mathrm{I}_{0(\min )}=0.1 \mathrm{I}_{0}=\left(\mathrm{I}_{2}-\mathrm{I}_{1}\right) / 2$ i.e. $\Delta \mathrm{I}=0.2 \mathrm{I}_{0}=0.66 \mathrm{~A}$

$$
\mathrm{L}=\left[5\left(\mathrm{~V}_{\mathrm{IN}}-\mathrm{V}_{0}\right) * \mathrm{~V}_{0} * \mathrm{~T}_{\mathrm{S}}\right] /\left[\mathrm{V}_{\mathrm{IN}} * \mathrm{I}_{0}\right]=32.15 \mu \mathrm{H}
$$

Step2: Calculation of Output capacitor $\left(\mathrm{C}_{0}\right)$ :

$\mathrm{C}_{0}=\left[(1-\mathrm{D}) * \mathrm{~T}_{\mathrm{S}}{ }^{2} * \mathrm{~V}_{0}\right] /\left[8 * \mathrm{~L}^{*} \Delta \mathrm{V}_{0}\right]=13.22 \mu \mathrm{F}$

Where $\Delta \mathrm{V}_{0}=$ Consider $1 \%$ of $\mathrm{V}_{0}$. 
Step3: Calculation of $\mathrm{R}_{\text {load }}$ :

$$
\mathrm{R}_{\text {load }}=\mathrm{V}_{0} / \mathrm{I}_{0}=1.91 \Omega .
$$

Simulation circuit:

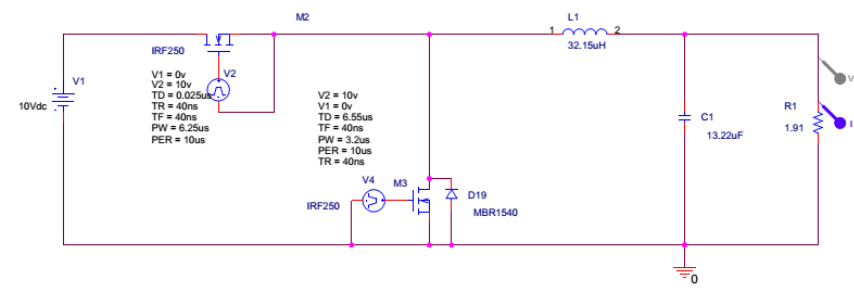

Fig -3.3: Schematic diagram of Synchronous buck converte

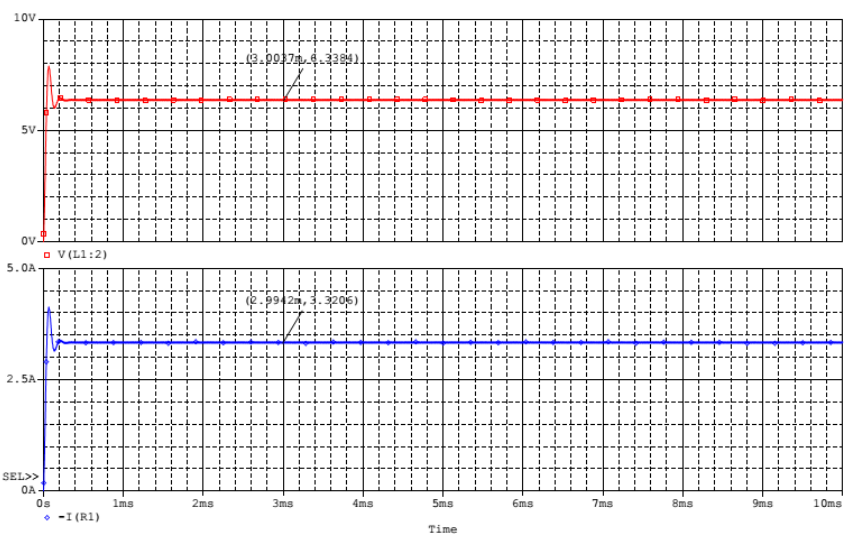

Fig -3.4: waveform of output voltage and output current of SR Buck converter.

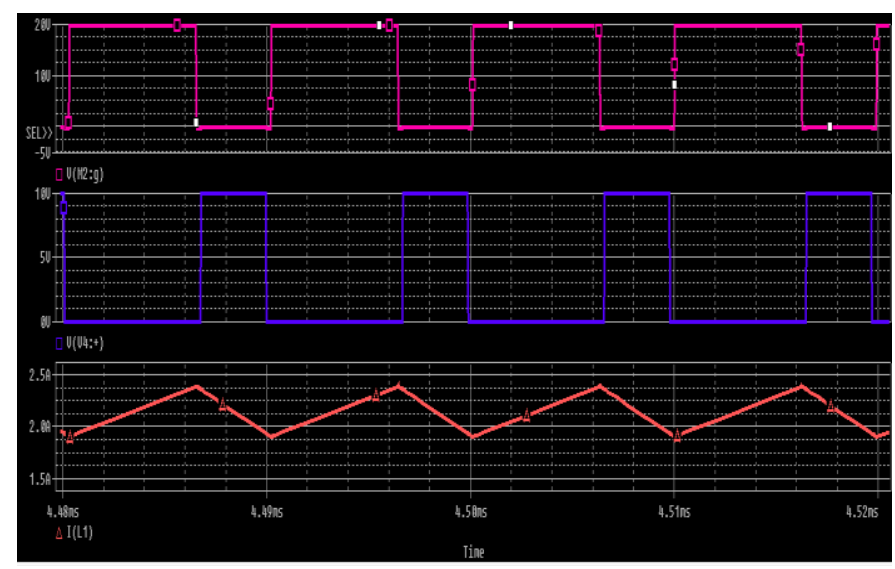

Fig -3.5: Waveform of gate pulse of mosfet M2 \& M3 and Inductor current.

\subsection{PWM Controller for Synchronous Buck Regulator}

The LM5116 is a synchronous buck controller intended for step-down regulator applications from a high voltage or widely varying input supply. The control method is based upon current mode control utilizing an emulated current ramp. Current mode control provides inherent line feed-forward, cycle by cycle current limiting and ease of loop compensation [8]. The use of an emulated control ramp reduces noise sensitivity of the pulse-width modulation circuit, allowing reliable control of very small duty cycles necessary in high input voltage applications [8]. The operating frequency is programmable from $50 \mathrm{kHz}$ to $1 \mathrm{MHz}$. The LM5116 drives external high-side and low-side NMOS power switches with adaptive dead time control [8].

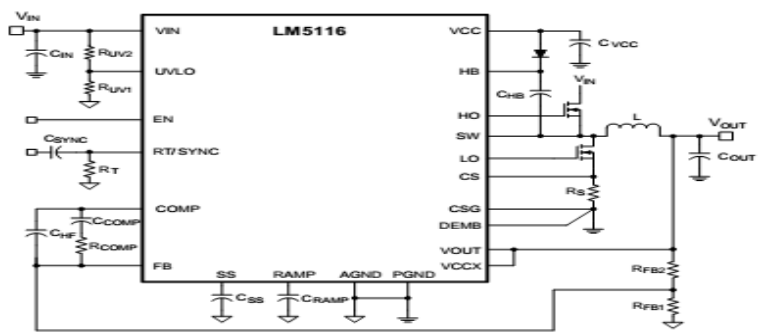

Fig -3.6: Typical application of LM5116[8].

\section{PROPOSED TOPOLOGY OF SYNCHRONOUS FLYBACK CONVERTER WITH SYNCHR- ONOUS BUCK POST REGULATOR}

In whole circuit, Secondary side of flyback converter will be floating on very high voltage line (i.e. $10 \mathrm{kv}$ or more).Therefore isolation is required between primary and secondary winding of flyback transformer. Also it is very difficult to take feedback signal for control circuit from secondary side of synchronous flyback converter to primary side, because voltage level of primary side is $28 \mathrm{~V}$ DC whereas voltage level of secondary side of flyback converter is $10 \mathrm{kv}$ with respect to ground, as shown in fig. 4.1. So synchronous buck post regulator is implemented for obtaining regulated output of $6.3 \mathrm{~V} \mathrm{DC}$ from $28 \pm 0.5 \mathrm{~V}$ DC input at $100 \mathrm{KHZ}$ frequency.

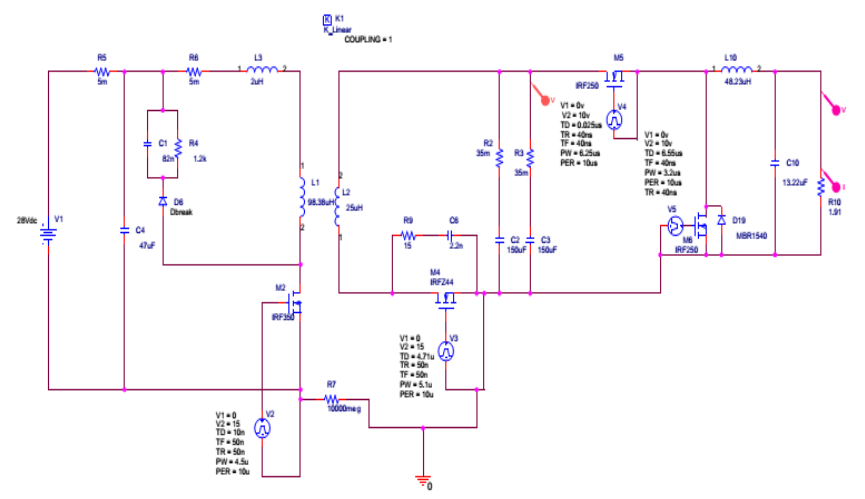

Fig -4.1: Schematic diagram of proposed circuit. 


\subsection{Simulation Result}

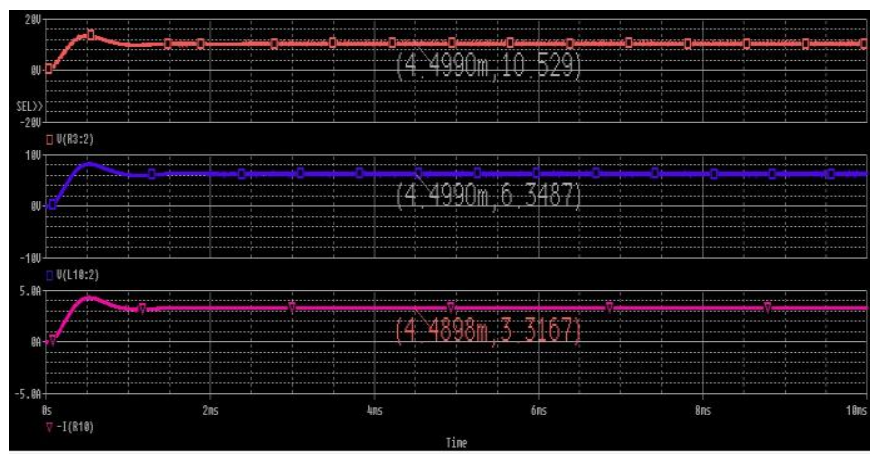

Fig -4.2: Waveform of input voltage of SR buck regulator and output voltage and output current of proposed topology.

\section{HARDWARE IMPLEMENTATION OF PROPOSED TOPOLOGY AND TESTING RESULT}

To implement the hardware as per proposed topology and design mentioned in sections 2.1, 2.2 and 3.3, cascaded circuit is used. In cascaded circuit, $1^{\text {st }}$ stage is synchronous flyback converter and $2^{\text {nd }}$ stage is synchronous buck regulator. Applied input is $28 \pm 0.5 \mathrm{~V} \mathrm{DC}$ with $100 \mathrm{kHz}$ switching frequency and regulated output of $6.6 \mathrm{~V} \mathrm{DC}$ obtained by using IC UC28025 in primary side of flyback converter, IC FAN6204 in secondary side of flyback converter and IC LM 5116 in $2^{\text {nd }}$ stage of cascaded circuit for regulation.

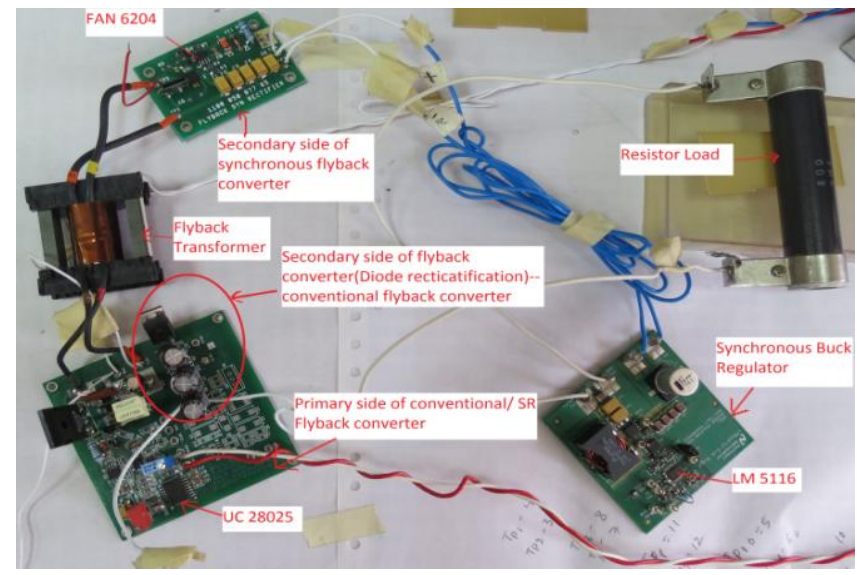

Fig -5.1: (a) Detailed hardware circuit

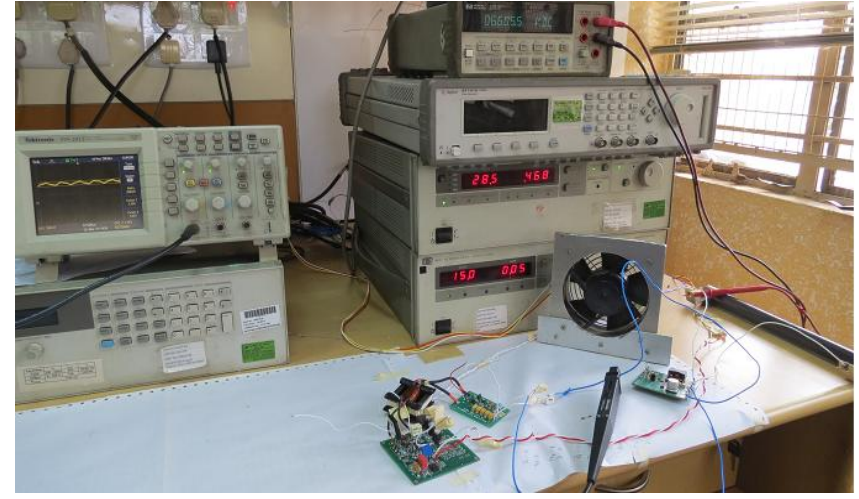

Fig -5.1: (b) Hardware circuit with output result at 3.9 $\mathrm{Load}$.

\subsection{Waveform of Hardware Circuit}

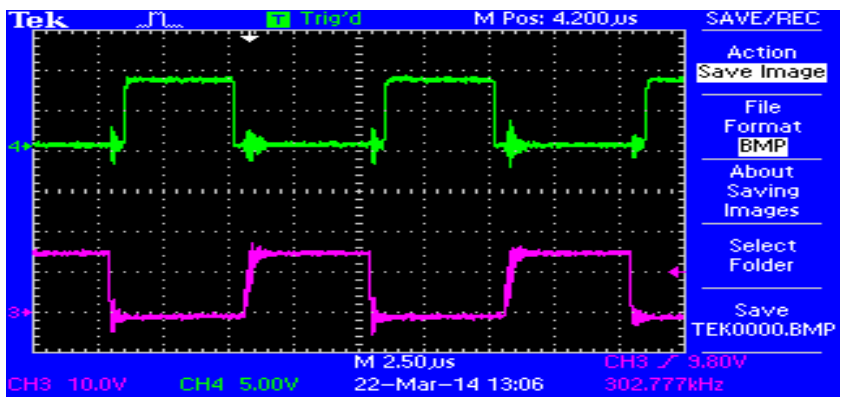

Fig -5.2: ch.3-prmary and ch.4 secondary gate pulse of synchronous flyback converter in proposed topology.

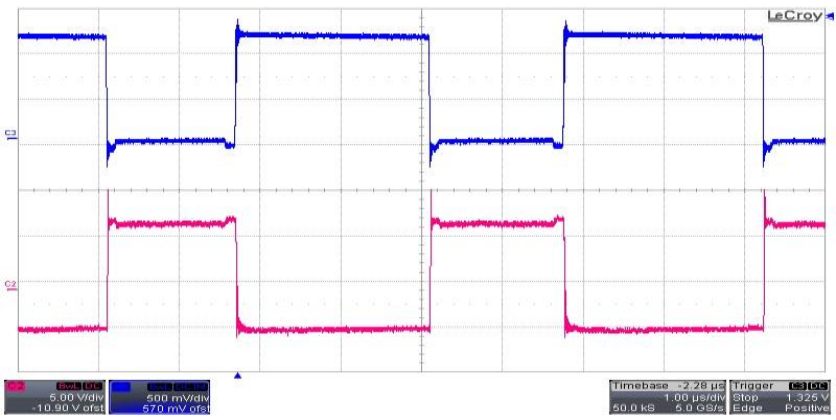

Fig -5.3:ch.3- primary and ch2. - Secondary mosfet voltage $\left(\mathrm{V}_{\mathrm{DS}}\right)$ of sync. Buck regulator in proposed topology.

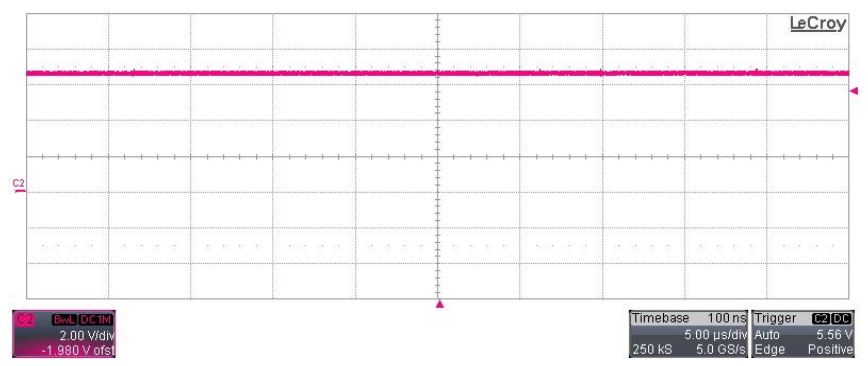

Fig -5.4: Regulated output voltage (6.6V) of proposed topology. 


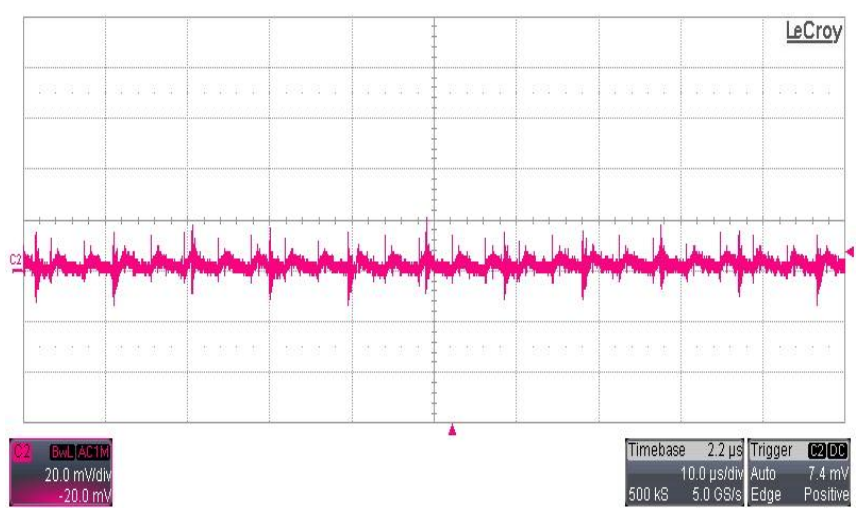

(a)

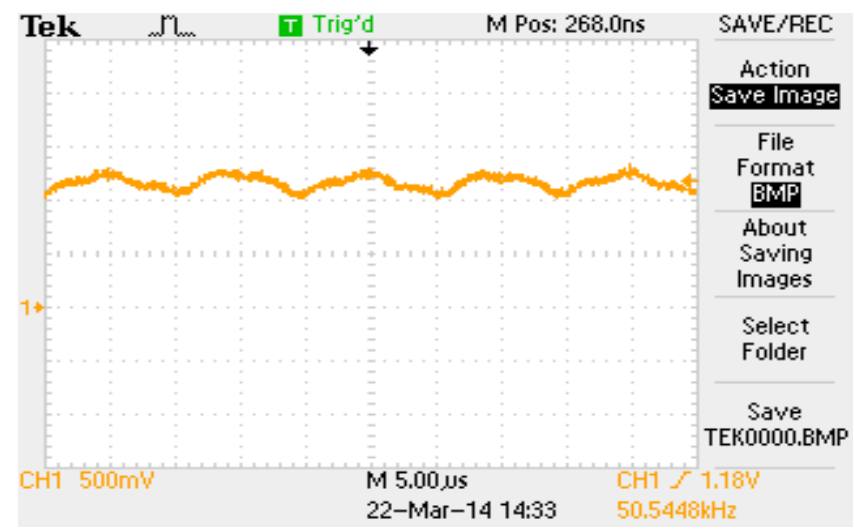

(b)

Fig -5.5: (a) Ripple voltage \& (b) Ripple current of proposed Topology.

\subsection{Testing Result of Hardware Circuit}

Table -1: Simple (conventional) flyback converter (open loop)

At The $\mathrm{R}_{\text {load }}=5 \Omega$

\begin{tabular}{|c|c|c|c|c|c|c|}
\hline $\begin{array}{c}\mathrm{V}_{\text {in }} \\
(\mathrm{V})\end{array}$ & $\begin{array}{c}\mathrm{I}_{\text {in }} \\
(\mathrm{A})\end{array}$ & $\begin{array}{c}\mathrm{P}_{\text {in }} \\
(\mathrm{W})\end{array}$ & $\begin{array}{c}\mathrm{V}_{\text {out }} \\
(\mathrm{V})\end{array}$ & $\begin{array}{c}\mathrm{I}_{\text {out }} \\
(\mathrm{A})\end{array}$ & $\begin{array}{c}\mathrm{P}_{\text {out }} \\
(\mathrm{W})\end{array}$ & $\begin{array}{c}\text { Efficiency } \\
(\%)\end{array}$ \\
\hline 27.5 & 0.727 & 19.99 & 9.39 & 1.84 & 17.28 & 86.42 \\
\hline 28 & 0.740 & 20.72 & 9.57 & 1.87 & 17.9 & 86.37 \\
\hline 28.5 & 0.757 & 21.57 & 9.76 & 1.91 & 18.64 & 86.41 \\
\hline
\end{tabular}

Table -2: Synchronous flyback converter (open loop)

When $R_{\text {load }}=5 \Omega$ (Full load)

\begin{tabular}{|c|c|c|c|c|c|c|}
\hline $\begin{array}{c}\mathrm{V}_{\text {in }} \\
(\mathrm{V})\end{array}$ & $\begin{array}{c}\mathrm{I}_{\text {in }} \\
(\mathrm{A})\end{array}$ & $\begin{array}{c}\mathrm{P}_{\text {in }} \\
(\mathrm{W})\end{array}$ & $\begin{array}{c}\mathrm{V}_{\text {out }} \\
(\mathrm{V})\end{array}$ & $\begin{array}{c}\mathrm{I}_{\text {out }} \\
(\mathrm{A})\end{array}$ & $\begin{array}{c}\mathrm{P}_{\text {out }} \\
(\mathrm{W})\end{array}$ & $\begin{array}{c}\text { Efficiency } \\
(\%)\end{array}$ \\
\hline 27.5 & 0.765 & 21.04 & 9.77 & 1.99 & 19.44 & 92.42 \\
\hline 28 & 0.778 & 21.78 & 9.92 & 2.02 & 20.04 & 91.99 \\
\hline 28.5 & 0.795 & 22.66 & 10.12 & 2.07 & 20.95 & 92.46 \\
\hline
\end{tabular}

Table -3: Only Synchronous Buck Regulator (Closed loop)

$$
\text { When } \mathrm{R}_{\text {load }}=2 \Omega
$$

\begin{tabular}{|c|c|c|c|c|c|c|}
\hline $\begin{array}{c}\mathrm{V}_{\text {in }} \\
(\mathrm{V})\end{array}$ & $\begin{array}{c}\mathrm{I}_{\text {in }} \\
(\mathrm{A})\end{array}$ & $\begin{array}{c}\mathrm{P}_{\text {in }} \\
(\mathrm{W})\end{array}$ & $\begin{array}{c}\mathrm{V}_{\text {out }} \\
(\mathrm{V})\end{array}$ & $\begin{array}{c}\mathrm{I}_{\text {out }} \\
(\mathrm{A})\end{array}$ & $\begin{array}{c}\mathrm{P}_{\text {out }} \\
(\mathrm{W})\end{array}$ & $\begin{array}{c}\text { Efficiency } \\
(\%)\end{array}$ \\
\hline 8.02 & 2.84 & 22.78 & 6.62 & 3.31 & 21.91 & 96.18 \\
\hline 9.06 & 2.52 & 22.83 & 6.62 & 3.31 & 21.91 & 95.97 \\
\hline 10.04 & 2.28 & 22.89 & 6.62 & 3.31 & 21.91 & 95.72 \\
\hline 11.02 & 2.09 & 23.03 & 6.62 & 3.31 & 21.91 & 95.14 \\
\hline 13.01 & 1.777 & 23.12 & 6.62 & 3.31 & 21.91 & 94.76 \\
\hline
\end{tabular}

Table - 4: Synchronous Flyback Converter Cascaded with Synchronous Buck Regulator (Full Hardware Circuit)

$$
\text { When } \mathrm{R}_{\text {load }}=2 \Omega
$$

\begin{tabular}{|c|c|c|c|c|c|c|}
\hline $\begin{array}{c}\mathrm{V}_{\text {in }} \\
(\mathrm{V})\end{array}$ & $\begin{array}{c}\mathrm{I}_{\text {in }} \\
(\mathrm{A})\end{array}$ & $\begin{array}{c}\mathrm{P}_{\text {in }} \\
(\mathrm{W})\end{array}$ & $\begin{array}{c}\mathrm{V}_{\text {out }} \\
(\mathrm{V})\end{array}$ & $\begin{array}{c}\mathrm{I}_{\text {out }} \\
(\mathrm{A})\end{array}$ & $\begin{array}{c}\mathrm{P}_{\text {out }} \\
(\mathrm{W})\end{array}$ & $\begin{array}{c}\text { Efficiency } \\
(\%)\end{array}$ \\
\hline 27.5 & 0.982 & 27.01 & 6.57 & 3.5 & 22.995 & 85.15 \\
\hline 28 & 0.969 & 27.13 & 6.57 & 3.5 & 22.995 & 84.75 \\
\hline 28.5 & 0.956 & 27.25 & 6.57 & 3.5 & 22.995 & 84.4 \\
\hline
\end{tabular}

\section{CONCLUSIONS}

Design of synchronous Flyback Converter with synchronous Buck post regulator is proposed in this paper. This proposed topology has several outstanding characteristics. We achieved low voltage drop, less power losses \& very high efficiency. It is suitable and simple to be used for power supplies with highPWM frequency and low-output voltage to reduce the rectification loss. Since secondary side of this scheme is less dissipative, it is best suitable for heater converter stage of TWT Power supply floating on high voltage where cooling is an issue.

\section{ACKNOWLEDGEMENTS}

The authors would like to acknowledge the partial financial support of Bharat Electronics Ltd., Bangalore, India and BMS college of Engineering, Bangalore, India for continuous support and guidance.

\section{REFERENCES}

[1]. Ali Emadi, Alireza Khaligh, Zhong Nie, Young Joo Lee, 'Integrated Power Electronic Converters and Digital Control', CRC Press, 2009.

[2]. Ionel Dan Jitaru, 'High Efficiency Flyback Converter using Synchronous Rectification', Applied Power Electronics Conference and Exposition, 2002. Seventeenth Annual IEEE, vol.2, pp. 867-871.

[3]. Jeongpyo Park, Yong-Seong Roh, Young-Jin Moon, and Changsik Yoo, 'A CCM/DCM Dual-Mode Synchronous Rectification Controller for a High-Efficiency Flyback Converter', IEEE Transactions On Power Electronics, vol.29, no. 2, February 2014, pp. 768-774. 
[4]. Daniel W. Hart, Introduction to Power Electronics, Prentice Hall, 1997.

[5]. Ned Mohan, Tore M Undeland, William P. Robbins, 'Power Electronics Converter, Applications, and Design', $3^{\text {rd }}$ EDITION Wiley India Edition, 2011.

[6]. Abraham I. Pressman, Keith Billings, Taylor Morey, 'Switching Power Supply Design', Mc Graw Hill, $3{ }^{\text {rd }}$ Edition 2009.

[7]. Application notes, 'FAN6204 Synchronous Rectification Controller for Flyback and Forward Freewheeling Rectification' by Fairchild Semiconductor Corporation, Dec. 2013.

[8]. Application notes, 'LM5116 Wide Range Synchronous Buck Controller' by Texas Instruments, Mar. 2013.

\section{BIOGRAPHIES}

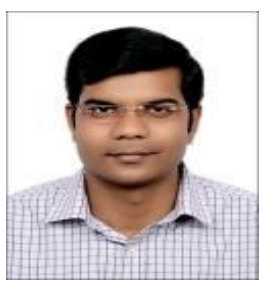

Navnit Kumar received the B.E degree in Medical Electronics from M.S Ramaiah Institute of Technology, VTU, Bangalore, India, in 2011, and is currently pursuing the M.Tech degree in Power Electronics from BMS College of Engineering, VTU, Bangalore, India. His research interest includes power supply design and power Electronics.

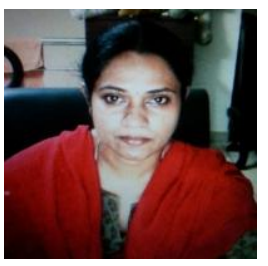

S. Pradeepa received B.E degree in Electrical \& Electronics Engineering from Annamalai University, in 1990; M.E in Power Electronics from Bangalore University in 1999 and doing research under VTU, Belgaum. She is currently working as Associate Professor in B.M.S. College of Engineering, Bangalore. Her area of interest is Power quality and Power Converters.

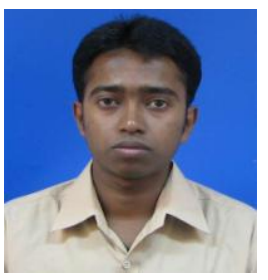

Mohan $\mathrm{H} \mathrm{R}$ received $\mathrm{BE}$ degree in Electronics and Communication from Malnad College of Engineering, Hassan, in 2006. Since 2006 he has been with Bharat Electronics Limited Bangalore involved in design and development of medium power Magnetron modulators, low to medium power supplies. He contributed towards indigenous development and realization of Magnetron based and TWT based Transmitters. 